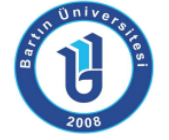

ISSN: 1308-7177
Bartin University

Journal of Faculty of Education

Volume 6, Issue 3, p. 1118-1133, October 2017

BARTIN - TURKEY

\title{
Ergenlerde Sır Saklamanın Duygusal Özerklik, Ahlaki Olgunluk, Yalnızlık, Utangaçlık ve Sosyal Destek Açısından İncelenmesi
}

Metin DENIZ, Doç. Dr., Bartın Üniversitesi Eğitim Fakültesi, metindeniz19@gmail.com

ORCID: http://orcid.org/0000-0002-5018-5408

Fuad BAKiOĞLU, Öğr. Gör. Gaziosmanpaşa Üniversitesi Eğitim Fakültesi, fuadpdr@hotmail.com

ORCID: http://orcid.org/0000-0002-9905-6199

Öz: Bu araştırmanın amacı, ergenlerde sır saklamanın çeşitli değişkenler açısından incelenmesidir. Araştırma kapsamında sır saklama ile duygusal özerlik, ahlaki olgunluk, yalnızlık, utangaçlık ve sosyal destek arasındaki ilişki incelenmiştir. Araştırmanın çalışma grubunu yaşları 15-19 arasında değişen, \% 71.1'i kız $(n=160), \% 28.9$ erkek $(n=65)$ olan toplan 225 birey oluşturmaktadır. Araştırmada "Kendini Gizleme Ölçeği", "Duygusal Özerklik Ölçeği", "Ahlaki Olgunluk Ölçeği", "UCLA Yalnızlık Ölçeği", "Utangaçlık Ölçeği”" ve "Sosyal Destek Ölçeği” kullanılmıştır. Araştırmada Bağımsız ttesti, ANOVA, Pearson korelasyon analizi ve aşamalı çoklu regresyon analizi kullanılmıştır. Araştırma bulgularına göre, ergenlerin cinsiyet ve kardeş sayısına göre sır saklama düzeylerinin farklılaşmadığı, sınıf düzeyi ve en uzun yaşanılan bölgeye göre sır saklama düzeylerinin farklılaştığı bulunmuştur. Yordanan ve yordayıcı değişkenler arasındaki ilişkilere bakıldığında sır saklama puanları ile yalnızlık ve utangaçık arasında pozitif yönde, ahlaki olgunluk, duygusal özerklik (idealleştirmeme, bireyleşme, bağımsızlık) ve sosyal destek arasında negatif yönde bir ilişki bulunmuştur. Ayrıca, regresyon modelinin istatistiksel olarak anlamlı olduğu ortaya konmuştur. destek

Anahtar Kelimeler: sır saklama, duygusal özerklik, ahlaki olgunluk, yalnızlık, utangaçık, sosyal

\section{An Investigation of Secrecy in Adolescents in Terms of Emotional Autonomy, Moral Maturity, Loneliness, Shyness and Social Support}

\begin{abstract}
The aim of this study is to investigate the secrecy in adolescence with respect to some developmental variables. In this study, the realitonships among secrecy and emotional autonomy, moral maturity, loneliness, shyness and social support were examined. The sample of this study consists of 225 adolescents (160 females and 65 males aged between $15-19$ years). "Self concealment Scale, "Emotional Autonomy Scale", "Moral Maturity Scale", "UCLA Loneliness Scale, "Shyness Scale" ve "Social Support Scale" were used to collect the data. In this sudy, Independent t test, ANOVA, Pearson correlletion coefficient and Stepwise multiple regression analysis were used. Results indicated that self concealment levels of the adolescents didn't differ significantly with respect to gender and number of siblings while it was found to differ significantly with respect to grade and the residential place lived the longest. However, there was significant positive correlations between self concealment scores and lonelines and shyness where as there was a negative correlations between self concealment and moral maturity, emotional autonomy and social support. Also, the regression model was found to significant statistically.
\end{abstract}

Key Words: secrecy, emotional autonomy, moral maturity, loneliness, shyness, social support 


\section{GíRiş}

Bireyin ergenlik dönemine girmesiyle beraber ailenin diğer fertleri ve akranlarıyla olan iletişim ve etkileşim tarzında değişim söz konusu olmaktadır. Birey çeşitli nedenlerle başkalarından sır saklama eğiliminde olmakta veya sınırlı sayıda kişiyle bazı sır olarak değerlendirilebilecek şeyler paylaşabilmektedir. Bireyin gizlediği sırlar genel olarak bireyin mahremiyet alanından farklı olarak görülmektedir. Mahremiyet bireyin özel alanını oluşturmaktadır. Bu özel alan dahilinde olan bilgiler, bireyin isteği doğrultusunda kendisine en yakın olan bireylerle bile paylaşımayabilir. Bu açıdan mahremiyet ve sır saklama birbirinden farklı olarak değerlendirilmektedir. Bununla birlikte, bazı kültürel yapılarda özellikle ergenlik dönemi sır saklama açısından riskli bir dönem olarak görülmektedir (Aadlansvik, 1997).

Sır saklama, bireyin kendisi veya başkaları ile ilgili her hangi bir bilgiyi bilinçli olarak kendisine saklama, kimse ile paylaşmaması eğiliminde olmasıdır (Bok, 1989; Kelly, 2002). Sır saklamanın birçok kuramsal açıklaması bulunmaktadır. Ket vurma kuramı açısından sır saklama ele alındığında, bireyin kendisini açmaması ya da duygularını gizlemesi bireyde fiziksel olarak yakınmalara neden olabilmektedir (Kelly ve Mckillop, 1996). Sosyal alan kuramı çerçevesinde sır saklama ele alındığında, kişisel, geleneksel ve ahlaki sır saklama alanları bulunmaktadır. Kişisel alanda sır saklama eylemi bireyin kendisi ile ilgili olan ve başkalarını etkilemeyen konuları kapsamaktadır (Nucci, 1981). Geleneksel alanda sır saklama bireyin toplumsal veya sosyal alanlarda benzer davranışlar göstermesi şeklindedir. Ahlaki alanda sır saklama, bireyin kendisi dışındaki alanı ilgilendirmektedir. Bireyin sır saklaması, başka bireylerin alanına girme, onları olumsuz etkileyebilecek sırları saklaması şeklinde görülmektedir (Turiel, 1983). Birey ahlaki gelişimine paralel olarak kendisi ya da başkalarıyla ilgili sırları, diğerlerine açıp açmaması konularında bir takım yargılar geliştirmektedirler. Bu bağlamda ele alındığında sır saklama ile ahlaki olgunluk arasında yakın bir ilişki olduğu değerlendirilebilir. Her ne kadar ergenlik döneminde olan bireyin sır saklamasının onun bireyleşmesine katkı sağlayacağı ortaya konmuş olsa da sır saklama genel bir bakış açısıyla olumsuz olarak değerlendirilebilecek bir takım fiziksel yakınmalar ve psikososyal sorunlarla ilişkilendirilmiştir (Larson ve Chastain, 1990; Kelly,1999; Finkenauer, Engels ve Meeus, 2002).

Ergenlerin sağlıklı bir şekilde yetişkinlik dönemine geçebilmeleri için yerine getirmeleri gereken görevlerden birisi de özerkliktir. Çoğu ergen için özerklik duygusu geliştirmek yetişkin olmanın bir parçası olan kimlik duygusunu geliştirmek kadar önemlidir (Noom, Dekovic ve Meeus, 2001). Ergenlik dönemin de fiziksel ve bilişsel alandaki değişiklikler, sosyal etkileşimin artması ve yeni sorumlulukların kazanımı ile özerklik gelişiminde büyük bir artış görülür.

Özerklik konusu, ergenlerin psikososyal gelişiminde kavramın farklı kullanımlarından kaynaklı olarak alan yazında tartışmalı olan konulardan birisidir. Ergenlerde özerlik, anababadan kopma (Freud, 1958), bireyleşmenin sonucu (Blos, 1979), akran ya da anababa baskısına karşı gelme (Berndt, 1979; Brittain, 1963; Devereux, 1970), anababa kontrolüne ya da kararına karşı bağımsız olma duygusu (Douvan ve Adelson, 1966; Elder, 1963; Kandel ve Lesser, 1972), kendi kararını alma ya da kendini yönetmede var olan güven (Greenberger, 1984), ahlaki, politik ve sosyal problem çözmede akıl yürütme ya da bağımsızlaşma (Adelson, 1972; Kohlberg ve Gilligan, 1972; Lewis, 1981) olarak kullanılmıştır (Akt: Steinberg ve Silverberg, 1986).

Özerklik tek boyutlu bir kavram değildir. Özerklik bazı araştırmacılar tarafından alt boyutlara ayrımıştır. Steinberg (2007), üç tür özerklik tanımlamıştır. Bunlar duygusal, davranışsal ve değer özerklikleridir. Değer özerkliği başkalarının istekleriyle uyuşmak için baskılara basit biçimde direnmekten çok, ergenlerin ahlaki, siyasi, ideolojik ve dinle ilgili konularda düşünmeler ve karar vermeleri ile tanımlanmaktadır. Davranışsal özerklik kişinin 
kendi davranışları üzerinde kontrol kurmaya başlaması ile ortaya çıkar. Daha gerçekçi ve uygun davranabilmek için gerektiğinde yardım istemek ve işbirliği yapmak davranışsal özerkliği ifade etmektedir. Duygusal özerklik ise ergenlerin anababalarından duygusal olarak daha bağımsız olmaya başlamaları olarak belirtilmiştir. Duygusal özerklik, anababa ve akranlardan duygusal olarak bağımsızlaşabilmenin duyuşsal sürecini ifade etmektedir. Duygusal özerklik gelişimiyle ilgili araştırmalar duygusal özerkliğin ergenliğin başında başlayan ve genç yetişkinliğe kadar devam eden uzun bir süreç olduğu belirtilmektedir.

Ahlaki olgunluk, ahlaki olarak kabul gören duygu, düşünce ve davranış açısından bireyin en üst düzeyde olma durumu olarak değerlendirilmektedir (Lickona, 1991). Ahlaki olgunluk ile ilgili kuramsal açıklamalar psikoanalitik kuram, davranışçı ve sosyal bilişsel kuram ve bilişsel gelişim kuramı açısından ele alınmaktadır. Psikoanalitik kuramda açısından ahlaki olgunluk, id ve süperego arasındaki dengenin ego tarafından kurulma çabası sonucunda gelişmektedir (Freud, 1997). Davranış̧ı ve sosyal bilişsel kuram çerçevesinde ahlaki olgunluk, ödül-ceza, model alma ve taklit yoluyla öğrenmelere dayanmaktadır (Çileli, 1981). Sosyal bilişsel kurama göre ahlaki davranış, birey tarafından davranışın sonuçlarının zihinde canlandırılması yoluyla olası olumsuz davranışlardan kaçınması ile edinileceği savunulmaktadır (Bandura, 2001). Bilişsel gelişim kuramına göre ahlaki gelişim, bilişsel veya zihinsel gelişim ile doğru orantılıdır. Bireyin ahlaki gelişimi dışa bağımlı olduğu dönemden, özerk ahlaki döneme doğru gelişme göstermektedir (Piaget, 2004). Kohlberg (1980)'e göre ahlaki gelişim, gelenek öncesi düzey (ceza ve itaat eğilimi, saf çıkarcı eğilim), geleneksel düzey (iyi çocuk olma eğilimi, yasa ve düzen eğilimi) ve gelenek sonrası düzey (anlaşma ve yasaya uygunluk eğilimi, evrensel ahlak ilkeleri eğilimi) olarak üç düzeyde ele alınmaktadır. Bireyin ahlaki gelişiminin sır saklama davranışıyla paralel bir seyir izlediği düşünülmektedir. Yani ahlaki olarak gelişmiş olan bireyin sır saklama davranışından kaçındığı dolayısıyla sır saklamanın olası olumsuz sonuçlarından kendisini koruduğu değerlendirilmektedir.

İnsan, doğası gereği içerisinde bulunduğu koşullara uyum sağlama eğilimindedir. Uyum sağlama süreci toplumsallaşmayı da beraberinde getirir. Sosyal bir varlık olan insanın, kendisini içerisinde bulunduğu çevresinden soyutlaması psikolojik açıdan bir risk faktörü olarak değerlendirebileceğimiz yalnızlığı da beraberinde getirir. Alanyazında yalnızlıkla ilişkili farklı tanımlamalar bulunmaktadır. Gün'e (2006) göre yalnızlık, bireyin çevresi ile ilişkisini azaltarak, kendi iradesi ile yaşadığı bir duygu halidir. Yalnızlık, tanımlanması güç, karmaşık ve sıkıntı verici bir yaşantıdır (Özkürkçügil,1998). Yalnızlık, bireyin sağlığını olumsuz yönde etkileyen ve biyolojik stresörleri tetikleyen psikolojik bir süreçtir (Steptoe, Owen, Kunz-Ebrecht ve Brydon, 2004). Alanyazında sır saklama ve yalnızlık arasında pozitif yönde ilişkinin olduğuna dönük bakış açısı, yalnızlığın, sır saklamanın olumsuz olası bir sonucu olduğu düşüncesini ortaya koymaktadır.

Kişilerarası ilişkilerdeki iletişim becerisi bireylerin sağlıklı ilişki kurabilmesinin de temelini oluşturur. Utangaçlık, genel anlamda kişilerarası ilişkilerden kaçınma ve rahatsızlık duymaya iliş̧in bir kavram olarak ele alınmaktadır. Enç'e (1980) göre utangaçlık, bireyin başkaları ile olan ilişkileri sırasında duyulan ve doğal davranışları ketleyen rahatsız edici bir duygudur. Utangaçlık, kişinin sadece sosyal ilişkilerini etkilemekle kalmaz aynı zamanda bireyin kendine değer veriş düzeyini, olaylara ve kişilere yönelik bilişsel yorumlamalarını da etkiler. Utangaç kişiler kendi düşünce ve davranışlarına fazlaca odaklanıp kendilerini suçlayıp ve başkaları tarafından olumsuz değerlendirilmekten korkarlar (Hamarta ve Demirbaş,2009). Psikososyal sorunlara neden olabileceği değerlendirilen sır saklamanın, bireyin sıkıntılı bir biçimde iletişim kurmaktan kaçınmasıyla açıklanan utangaçıkla ilişkisi olduğu düşünülmektedir. 
Sır saklama ile sosyal destek arasında yakın bir ilişkinin olduğu ve özellikle ergenlerin sakladıkları sırları anababalarına anlattıkları, dolayısıyla sır saklamanın olumsuz sonuçlarından kendisini bu sayede koruduğu açıktır. Yapılmış olan araştırmalarda, ergenlerin özellikle sırlarını anneye anlatma eğiliminde oldukları ve bu durumun annenin bir otorite figürü olarak ergeni zor duruma sokmamasının rolünün etkili olduğu düşünülmektedir (Youniss ve Smollar, 1985; Smetana, Metzger, Gettman, ve Campione-Barr, 2006 ). Bununla beraber sır saklama eğiliminde olan bireylerin utangaçlık ve depresyon gibi bazı psikolojik problemler yaşadığı belirlenmiştir (Kelly, 1999). Bundan da anlaşılacağı üzere, sır saklayan bireylerin utangaç tavırlar sergilediği ve bu durumun onun tüm sosyal yaşantısını etkileyebileceği düşünülmektedir. Öyle ki sosyal yaşantıdan soyutlanmış olan bireyin gittikçe yalnızlaşacağı ve diğer insanlarla sağlıklı sosyal ilişkiler kuramayacağı değerlendirilmektedir.

$\mathrm{Bu}$ araştırmanın, amacı ergenlerin sır saklama puanlarının çeşitli değişkenler açısından incelenmesidir. Bu amaç çerçevesinde aşağıdaki alt problemlere yanıt aranacaktır. Bu araştırmada, ergenlerin sır saklama düzeylerinin cinsiyet, sınıf düzeyi, kardeş sayısı ve en uzun yaşadıkları bölgeye göre farklılaşıp farklılaşmadığını incelenmiştir. Ayrıca, sır saklama ile ahlaki olgunluk, duygusal özerklik (idealleştirmeme, bağımsızlık, bireyleşme), yalnızlık, utangaçlık ve algılanan sosyal destek arasında anlamlı bir ilişki olup olmadığı incelenmiştir. Bununla birlikte, ahlaki olgunluk, duygusal özerklik (bireyleşme, idealleştirmeme, bağımsızlık), yalnızlık, utangaçlık ve algılanan sosyal desteğin ergenlerin sır saklamasını yordayıp yordamadığı ortaya konmuştur.

\section{YÖNTEM}

\subsection{Araştırmanın Modeli}

Bu araştırma ahlaki olgunluk, duygusal özerlik, yalnızlık, utangaçlık ve sosyal destek değişkenlerinin sır saklamayı ne ölçüde yordadıkları ve adı geçen değişkenler arasındaki ilişkilerin incelendiği tarama modelinin kullanıldığı bir araştırmadır. Tarama modeli " geçmişte ve günümüzde var olan bir durumun olduğu gibi yansıtılmasını sağlayan ve araştırma konusu olan bireyin kendi koşulları içerisinde değerlendiren betimsel bir araştırma yöntemidir" (Karasar, 2004, s. 77). Bu araştırmanın bağımlı değişkeni sır saklama, bağımsız değiş̧kenleri ise duygusal özerklik, ahlaki olgunluk, yalnızlık, utangaçlık ve sosyal destektir.

\section{2. Çalışma Grubu}

Bu araştırmanın çalışma grubunu 2013-2014 eğitim öğretim yılında orta öğretim düzeyinde öğrenimine devam eden $160 \mathrm{kız} \mathrm{( \%} \mathrm{71.1)} \mathrm{ve} 65$ erkek (\% 28.9) olmak üzere toplam 225 ergen oluşturmaktadır. Araştırmaya katılan ergenlerin 35'i dokuzuncu sınıf (\% 15.6), 120'si onuncu sınıf (\% 53.3) ve 70'i on birinci sınıf (\% 31.1) düzeyindedir. Çalışma grubunda bulunan ergenlerin yaş ortalaması 16.26 ve yaşları 15-19 arasında değişmektedir. Katılımcıların 36'sının bir kardeşi (\% 16.0), 60'ının iki kardeşi (\% 26.7), 76'sının üç kardeşi (\% 33.8), 29'unun dört kardeşi (\% 12.9) ve 24 'ünün beş ve üzeri sayıda kardeşi (\% 10.7) bulunmaktadır. Araştırmaya katılanların en uzun süre yaşadıkları yerleşim birimi olarak 58'i (\% 25.8) köy, 15'i (\% 6.7) kasaba, 20 'si (\% 8.9) ilçe ve 132'si (\% 58.7) il merkezinde yaşadıklarını belirtmişlerdir. Çalışma grubunun $179^{\prime} u$ anne babası ile birlikte (\% 79.6), 1'i annesi ile birlikte (\% .4), 1'i babası ile birlikte (\% .4), 42'si anne baba ve akrabalarıyla birlikte $(\%$ 18.7) ve 2'si yurtta (\% .9) kalmaktadır.

\subsection{Veri Toplama Araçları}

Araştırmanın bu bölümünde araştırma kapsamında kullanılan ölçme araçları ile ilgili bilgiler sunulmaktadır. 


\section{Kişisel Bilgi Formu}

Çalışma grubunda yer alan ergenlerin cinsiyet, sınıf düzeyi, yaşları, kardeş sayısı, en uzun yaşanılan yerleşim birimi, kiminle birlikte yaşadığı ile ilgili bilgiler kişisel bilgi formu yoluyla elde edilmiştir.

\section{Kendini Gizleme Ölçeği}

Larson ve Chastain (1990) tarafından geliştirilen ölçek Deniz ve Çok (2010) tarafından Türkçeye uyarlanmıştır. Ölçek 10 maddeden oluşmaktadır. Ölçek maddeleri, "sırrı kendine saklanma, diğerleri ile paylaşılmayacak bir sırra sahip olma ve saklanan kişisel bilginin açıklanmasını" ölçen maddelerden oluşmaktadır. Ölçekte 5'li Likert derecelendirmesi "1-Bana hiç uygun değil-5-Bana tamamen uygun" kullanılmıştır. Ölçekten alınabilecek en düşük puan 10, en yüksek puan ise 50 'dir. Ölçekten alınan puan yükseldikçe kendini gizleme düzeyi artmaktadır. Ölçek Cronbach alfa iç turtarlılık kat sayısı .83 olarak bulunmuştur. Test tekrar test güvenirlik kat sayısı 81 olarak bulunmuştur.

Ölçeğin Türkçeye uyarlanması konusunda ölçeğin yazarından izin alındıktan sonra 6 alan uzmanı tarafından Türkçeye çevirisi yapılmıştır. Ölçek geri çevirisi iki alan uzmanı tarafından yapılmıştır. Daha sonra ölçek yazarı ve uzman görüşleri dikkate alınarak ölçek formu oluşturulmuştur. Ölçeğin güvenirlik çalışması kapsamında Cronbach alfa iç tutarlılık kat sayısı .86 olarak bulunmuştur. Madde ayırt edicilik ve madde toplam korelasyonları hesaplanmıştır. Madde toplam korelasyonları .41 ile .66 arasında değişmektedir. Yapı geçerliğini belirlemek amacıyla açımlayıcı ve doğrulayıcı faktör analizi yapıımıştır. açımlayıcı faktör analizinde faktör yük değerleri .51 ile .74 arasında değişmektedir. Doğrulayıcı faktör analizi sonucunda tek faktörlü bir model kabul edilmiştir. Türkçeye uyarlaması yapılan ölçeğin güvenilir ve geçerli bir ölçek olduğu değerlendirilmektedir (Deniz ve Çok, 2010).

\section{Duygusal Özerklik Ölçeği}

Steinberg ve Silverberg (1986) tarafından geliştirilen "Duygusal Özerklik Ölçeği (Emotinal Autonomy Scale)" Deniz, Çok ve Duyan (2010) tarafından Türkçeye uyarlanmıştır. Orijinal ölçek, dört alt ölçekten oluşmaktadır. Ölçeğin "idealleştirmeme" ve "anababayı birey olarak görme" gibi ikisi bilişsel, "bağımsızık" ve "bireyleşme" gibi ikisi duyuşsal alt boyutu bulunmaktadır. Ölçek 4'lü Likert "1-Bana hiç uygun değil - 4-Bana tamamen uygun" tipindedir. Ölçek puanlamasında alt ölçek puanları ve ölçek toplam puanı dikkate alınabilmektedir. Orijinal Ölçek toplam Cronbach alfa iç tutarlılık kat sayısı .75, idealleştirmeme alt ölçeği için .63, anababayı birey olarak görme alt ölçeği için .61 , bağımsızlık alt ölçeği için .51 ve bireyleşme alt ölçeği için .60 olarak bulunmuştur.

Ölçek uyarlama çalışması ölçek yazarından alınan izinler doğrultusunda altı alan uzmanı tarafından Türkçeye çevirisi yapılmıştır. İki alan uzmanı tarafından geri çevirisi yapılan ölçek, ölçek yazarının bilgilendirilmesi ve uzman önerilerinin de dikkate alınması sonucunda ölçek formu oluşturulmuştur. Verilerin toplanmasından sonra, güvenirlik çalışması kapsamında ölçek Cronbach toplamı için alfa iç tutarlılık kat sayısı .79, idealleştirmeme alt ölçeği için .71, bağımsızlık alt ölçeği için .64 ve bireyleşme alt ölçeği için .67 olarak bulunmuştur. Yapı geçerliğinin test edilebilmesi amacıyla doğrulayıcı faktör analizi yapılmıştır. Doğrulayıcı faktör analizi sonucunda ölçek yapısının doğrulandığı görülmüştür. Anababayı birey olarak görme alt ölçeği önceki çalışmalarda duygusal özerkliğe katkııının az olması ve madde toplam 
korelasyonlarının istenen düzeyde olmamasından dolayı faktör analizi kapsamına alınmamıştır. Üç faktörlü yapı doğrulayıcı faktör analizinde doğrulanmıştır ve madde uyum indekslerinin kabul edilebilir düzeyde olduğu görülmüştür. Uyarlanmış olan ölçekte üç alt ölçek bulunmaktadır. Ölçeğin "bağımsızlık" alt ölçeğinde 2, 4, 5, 9. maddeler; "idealleştirmeme" alt ölçeğinde 1, 3, 8, 11, 13. maddeler ve "bireyselleşme" alt ölçeğinde $6,7,10,12$, 14. maddeler yer almaktadır. Ölçek toplam 14 maddeden oluşmaktadır. Ölçekte 4, 6, 10, 12, ve 14. maddeler ters kodlanmaktadır. Yapılan analizler sonucunda ölçeğin Türkçeye uyarlanması sağlanmış güvenilir ve geçerli bir ölçek olarak değerlendirilmiştir (Deniz, 2010).

\section{Ahlaki Olgunluk Ölçeği}

Şengün ve Kaya (2007) tarafından geliştirilmiş olan Ahlaki Olgunluk Ölçeği ile bireylerin ahlaki olgunluk düzeylerinin belirlenmesi amaçlanmaktadır. 5'li Likert tipinde olan ölçekte 66 madde bulunmaktadır. Ölçekteki olumlu ifade edilen maddeler için "evet her zaman" seçeneği 5 puan, "çoğu zaman" seçeneği 4 puan, "ara sıra" seçeneği 3 puan, "çok nadir" seçeneği 2 puan, "hayır hiçbir zaman" seçeneği 1 puan şeklinde derecelendirilmiştir. Olumsuz ifade edilen maddeler ise ters yönden puanlanmaktadır. Ölçekte 52 olumlu ifadeli madde, 14 olumsuz ifadeli madde yer almaktadır. Ölçekten en yüksek 330 puan, en düşük 66 puan alınmaktadır. Ölçekten alınan puan yükseldikçe ahlaki olgunluk düzeyi yükselmekte, alınan puan düştükçe ahlaki olgunluk düzeyi düşmektedir.

Ölçeğin güvenirlik ve geçerlik çalışması 830 kişi ile yapılmıştır. Ahlaki olgunluk ölçeğinin geçerlik çalışması kapsamında uzman görüşleri alınmış, yapı geçerliği için faktör analizi yapılmıştır. Yapılan faktör analizi sonucunda ölçek maddeleri birinci faktörde toplanmıştır. Madde analizi sonucunda madde toplam korelasyon katsayısı anlamlı bulunmuştur $(p<.001)$. Ahlaki olgunluk ölçeği güvenirlik çalışması kapsamında test-tekrar test, test-yarı test ve Cronbach alfa güvenirlik kontrol yöntemleri kullanılmıştır. Ahlaki olgunluk ölçeğinin test-tekrar test güvenirlik katsayısı .84 , test-yarı test güvenirlik katsayısı .89 bulunmuştur. ayrıca ölçeğin Cronbach alfa iç tutarlılık katsayısı ise .95 olarak kaydedilmiştir.

\section{Yalnızlık Ölçeği}

Bireylerin yalnızlık düzeylerini belirlemek amacıyla Russel, Peplau ve Ferguson (1978) tarafından geliştirilmiş olan "UCLA Yalnızlık Ölçeği" (University of California Los Angeles Loneliness Scale) Demir (1989) tarafından Türkçeye uyarlanmıştır. Ölçek 20 maddeden oluşmaktadır. Ölçekteki maddelerden 10 tanesi düz, 10 tanesi ters kodlanmaktadır. Ölçek maddelerinde bahsi geçen durumu bireylerin ne sıklıkla yaşadıklarını belirtmelerini isteyen ölçek 4'lü Likert tipindedir. Ölçekte, olumlu ifadeli maddelerde "hiç yaşamam" 4, "nadiren yaşarım" 3, "bazen yaşarım" 2, "sık sık yaşarım" 1 puan olarak değerlendirilirken; olumsuz ifadeli maddelerde "hiç yaşamam" 1, "nadiren yaşarım" 2, "bazen yaşarım" 3, "sık sık yaşarım" 4 puan verilerek puanlama yapılmaktadır. Ölçekten alınabilecek puan 20-80 arasında değişmektedir. Ölçekten alınan puan arttıkça yalnızlık düzeyinin arttığı değerlendirilmektedir (Demir, 1989). Güvenirlik çalışması kapsamında ilk form ile 1980 'de gözden geçirilen form arasında .91 düzeyinde bir korelasyon değeri elde edilmiştir. Ölçek güvenirliği kapsamında elde edilen Cronbach alfa iç tutarlılık katsayısı 96 olarak bulunmuştur. Beş hafta sonra yapılan test tekrar test güvenirlik kat sayısı .94 olarak bulunmuştur.

\section{Sosyal Destek Ölçeği}

Sosyal destek ölçeği bireylerin aile ve arkadaşlarından algıladığı destek düzeyini belirlemek amacıyla Procidano ve Heller (1983, Akt: Eskin, 1993) tarafından geliştirilmiştir. Sosyal Destek 
Ölçeği, aile ve arkadaş sosyal destek ölçeği olmak üzere 2 ölçekten oluşmaktadır. Bu çalışmada aile sosyal destek ölçeği kullanılmıştır. Bu ölçek 20 maddeden oluşmaktadır. Ölçekte "Evet", "Hayır" ve "Bilmiyorum" seçenekleri yer almaktadır. Ölçekteki her madde için bireylerin bu seçeneklerden birisini seçmesi istenmektedir. Ölçeğin puanlaması, her madde için "evet" seçeneği " +1 " puan anlamına gelmektedir. "Hayır" seçeneği " 0 " puan, yani sosyal desteğin olmadığı anlamına gelmektedir. Ölçekteki "Bilmiyorum" seçeneğine puanlama yapılmamaktadır. Ölçekten alınabilecek puan 0-20 arasında değişmektedir. Puan yükseldikçe algılanan sosyal desteğin arttığı değerlendirilmektedir. Ölçek yapı geçerliği kapsamında yapılan analizler sonucunda ölçek maddelerinin tek faktörde toplandığı görülmüştür. Algılanan Sosyal Destek Ölçeği- Arkadaş Formu (ASD-AR) için ölçek Cronbach alfa iç tutarlılık katsayısı .88, Algılanan Sosyal Destek Ölçeği- Aile Formu (ASD-AL) için Cronbach alfa iç tutarlılık katsayısı .90 olarak bulunmuştur. Bir ay arayla yapılan test-tekrar test uygulaması sonucu her iki ölçek için de güvenirlik kat sayısı .83 bulunmuştur. Ölçeğin Türkçe'ye uyarlama çalışması Eskin (1993) tarafından yapılmıştır. Ölçeğin uygulaması sonucunda yapılan analizlerde ASD-AR ölçeği için Cronbach alfa iç tutarlııık katsayısı .76, ASD-AL ölçeği için Cronbach alfa iç tutarlılık katsayısı 85 olarak bulunmuştur. Test tekrar test güvenirlik kat sayıSI ASD-AR ölçeği için .80, ASD-AL için .90 olarak bulunmuştur.

\section{Utangaçlık Ölçeği}

Cheek (1990) tarafından bireylerin utangaçlık düzeylerini belirlemek amacıyla geliştirilmiş olan "Utangaçlık Ölçeği" Güngör (2001) tarafından Türkçeye uyarlanmıştır. Ölçeğin uyarlama çalışması iki aşamadan oluşmaktadır. İlk olarak "Shyness Scale" 'nın Türkçeye çevirisi yapılarak, uzman görüşleri doğrultusunda ölçeğin 13 maddesi oluşturulmuştur. İkinci aşamada, 300 katılımcının olduğu bir örnekleme "kendilerini hangi durumda utangaç hissettiklerine" dair açık uçlu bir soru sorulmuş. Cevaplar doğrultusunda bir liste çıkartılmıştır. Elde edilen liste Cheek'in 13 maddelik ölçeği ile karşılaştırılarak aynı olan maddeler çıkartılmış, geriye kalan 7 madde 13 maddelik ölçeğe eklenerek yeni ölçek oluşturulmuştur. Ölçek $5^{\prime}$ li Likert tipinde olup, toplam 20 maddeden oluşmaktadır. Ölçek "Bana Hiç Uygun Değil-1", "Bana Uygun Değil-2", "Karasızım3", "Bana Uygun-4", "Bana Çok Uygun-5" şeklinde puanlanmaktadır. Ölçekten alınabilecek en yüksek puan 100 , en düşük puan $20^{\prime}$ dir. Ölçekten alınan puan yükseldikçe utangaçlık düzeyi de yükselmektedir.

Ölçek güvenirlik çalışması kapsamında test tekrar test yöntemi sonucu korelasyon katsayısı .83 olarak bulunmuştur. Ölçeğin iç tutarlılık çalışması kapsamında Cronbach alfa korelasyon katsayısı .91 olarak ölçülmüştür. Ölçeğin geçerlik çalışması kapsamında yapı geçerliği ve benzer ölçekler geçerliği yöntemleri kullanılmıştır. Benzer ölçek geçerliği kapsamında "Sosyal Durumlarda Kendini Değerlendirme Envanteri" (SDKDE) ile "Utangaçlık ölçeği" beraber uygulanmıştır. Utangaçlık Ölçeğinin SDKDE ölçeğinin kaygı ve kaçınma düzeyi toplam puanları arasında .71 korelasyon olarak bulunurken, SDKDE ölçeğinin kaçınma düzeyi ile arasında .78 korelasyon bulunmuştur. Ayrıca yapı geçerliği kapsamında yapılan analizler sonucunda ölçeğin tek boyutlu olduğu değerlendirilmiştir.

\subsection{Veri Analizi ve İşlem}

Bu araştırmadan elde edilen verilerin istatistiksel çözümlemeleri SPSS 15.00 (Sosyal Bilimler İçin İstatistik Programı) paket programı kullanılarak yapılmıştır. Araştırmaya katılanların demografik özellikleri yüzde ve frekans dağılımı analiz yöntemleriyle yapılmıştır. Demografik değişkenlere göre sır saklama düzeyinin farklılaşıp farklılaşmadığı belirlemek amacıyla ilişkisiz t testi ve ANOVA analizi yapılmıştır. Sır saklamanın diğer değişkenlerle olan ilişkisini belirlemek amacıyla pearson korelasyon yöntemi ve sır saklamanın yordayıcılarını 
belirlemek için aşamalı çoklu regresyon analiz yöntemi kullanılmıştır. Veriler, araştırmacılar tarafından bizzat toplanmıştır. Verilerin toplanması katılımcıların gönüllülükleri dikkate alınarak yapılmıştır. Gönüllü olan katılımcıların 40 dakikalık bir zaman diliminde ölçekleri doldurması yoluyla veriler elde edilmiştir.

\section{BULGULAR}

Araştırmanın bu kısmında, araştırmanın amaçları çerçevesinde elde edilen bulgu ve yorumlara yer verilmiştir. Sır saklama düzeyinin demografik değişkenlere göre farklılaşıp farklılaşmadığını belirlemeye yönelik yapılan analiz sonuçları aşağıda sunulmuştur. Cinsiyete göre ergenlerin sır saklama puan ortalamalarının anlamlı düzeyde farklılaşıp farklılaşmadığına ilişkin bağımsız gruplar için t-testi sonucunda kız ve erkeklerin sır saklama puan ortalamaları arasındaki fark manidar bulunmamıştır $\left[t_{(223)}=-2.72 ; p>.05\right]$. Bu kapsamda elde edilen sonuçlar Tablo 1'de sunulmuştur.

Tablo 1. Cinsiyete göre sır saklama puanları arasındaki fark

\begin{tabular}{lllllll}
\hline Cinsiyet & $\mathrm{N}$ & $\bar{X}$ & $\mathrm{~S}$ & $\mathrm{Sd}$ & $\mathrm{T}$ & $\mathrm{P}$ \\
\hline Erkek & 65 & 22.82 & 6.24 & 223 & -2.72 & .56 \\
$\mathrm{~K} \mathrm{Iz}$ & 160 & 20.20 & 6.67 & & & \\
\hline
\end{tabular}

Ergenlerin sınıf düzeyine göre sır saklama puan ortalamalarının farklılaşıp farklılaşmadığına yönelik yapılan ANOVA analizi sonucunda, ergenlerin sır saklama puan ortalamalarının sınıf düzeyine göre manidar şekilde farklılaştığı bulunmuştur $\left[F_{(2 ; 222)}=7.62\right.$; p<.01]. bu kapsamda elde edilen sonuçlar Tablo 2'de sunulmuştur.

Tablo 2. Sınıf düzeyine göre sır saklama puanları arasındaki fark

\begin{tabular}{lllllll}
\hline $\begin{array}{l}\text { Varyansın } \\
\text { kaynağı }\end{array}$ & $\begin{array}{l}\text { Kareler } \\
\text { toplamı }\end{array}$ & Sd & $\begin{array}{l}\text { Kareler } \\
\text { ortalaması }\end{array}$ & $\mathrm{F}$ & $\mathrm{P}$ & $\begin{array}{l}\text { Anlamlı } \\
\text { fark }\end{array}$ \\
\hline $\begin{array}{l}\text { Gruplararası } \\
\text { Grupiçi }\end{array}$ & 634.775 & 2 & 317,387 & 7.62 & .001 & $9-11$ \\
Toplam & 9246.781 & 222 & 41.652 & & & \\
\hline
\end{tabular}

Puan ortalamaları arasındaki farkların, hangi sınıf düzeyleri arasında olduğunu belirlemek amacıyla Scheffe testi yapılmıştır. Elde edilen sonuçlara göre, on birinci sınıfta öğrenim gören katılımcıların sır saklama puan ortalamaları $(\bar{X}=22.83)$ dokuzuncu sınıfta öğrenim gören katılımcıların sır saklama puan ortalamalarından $(\bar{X}=17.63)$ manidar düzeyde yüksek olduğu bulunmuştur.

Katılımcıların kardeş sayılarına göre sır saklama puanları arasında farklılaşma olup olmadığını belirlemeye yönelik yapılan ANOVA analizi sonucunda, sır saklama puan ortalamalarının kardeş sayılarına göre manidar bir şekilde farklılaşmadığı görülmektedir $\left[F_{(4 ; 220)}=3.12 ; p<.01\right]$. Elde edilen sonuçlar Tablo 3'de sunulmuştur. 
Tablo 3. Kardeş sayılarına göre sır saklama puanları arasındaki fark

\begin{tabular}{lllllll}
\hline $\begin{array}{l}\text { Varyansın } \\
\text { kaynağı }\end{array}$ & $\begin{array}{l}\text { Kareler } \\
\text { toplamı }\end{array}$ & $\mathrm{Sd}$ & $\begin{array}{l}\text { Kareler } \\
\text { ortalaması }\end{array}$ & $\mathrm{F}$ & $\mathrm{p}$ & $\begin{array}{l}\text { Anlamlı } \\
\text { fark }\end{array}$ \\
\hline Gruplararası & 530.494 & 4 & 132.624 & 3.12 & .016 & - \\
$\begin{array}{l}\text { Grupiçi } \\
\text { Toplam }\end{array}$ & 9351.061 & 220 & 42.505 & & & \\
\hline
\end{tabular}

Katılımcıların en uzun süre yaşadıkları yerleşim birimine göre sır saklama puanları arasında farklılaşma olup olmadığını belirlemeye yönelik yapılan ANOVA analizi sonucunda, katılımcıların sır saklama puan ortalamalarının en uzun süre yaşanılan yerleşim birimine göre manidar bir şekilde farklılaştığı görülmektedir $\left[F_{(3 ; 221)}=5.14 ; p<.01\right]$. Elde edilen sonuçlar Tablo 4 'de sunulmuştur.

Tablo 4. En uzun yaşanılan yerleşim birimine göre sır saklama puanları arasındaki fark

\begin{tabular}{lllllll}
\hline $\begin{array}{l}\text { Varyansın } \\
\text { kaynağı }\end{array}$ & $\begin{array}{l}\text { Kareler } \\
\text { toplamı }\end{array}$ & $\mathrm{Sd}$ & $\begin{array}{l}\text { Kareler } \\
\text { ortalaması }\end{array}$ & $\mathrm{F}$ & $\mathrm{p}$ & $\begin{array}{l}\text { Anlamlı } \\
\text { fark }\end{array}$ \\
\hline $\begin{array}{l}\text { Gruplararası } \\
\text { Grupiçi }\end{array}$ & 644.897 & 3 & 214.966 & 5.14 & .002 & Köy-II \\
Toplam & 9236.659 & 221 & 41.795 & & & \\
\hline
\end{tabular}

Katılımcıların puan ortalamaları arasındaki farkların, en uzun yaşanılan hangi yerleşim birimleri arasında olduğunu belirlemek amacıyla Scheffe testi yapılmıştır. Elde edilen sonuçlara göre, en uzun süre köyde yaşayan katılımcıların sır saklama puan ortalamaları ( $\bar{X}=23.52$ ) en uzun süre şehirde yaşayan katılımcıların sır saklama puan ortalamalarından $(\bar{X}=19.92)$ manidar düzeyde yüksek olduğu bulunmuştur.

\section{Korelasyon analizi sonuçları}

Bu bölümde yordayıcı olan değişkenler (ahlaki olgunluk, idealleştirmeme, bağımsızlık, bireyleşme, sosyal destek, yalnızlık, utangaçlık) ile yordanan değişken (sır saklama) arasındaki ilişkileri içeren korelasyon analizine ilişkin bulgulara yer verilmiştir.

Tablo 5. Yordanan ve Yordayııı Değişkenlere Ait Ortalama ve Standart Sapmalar

\begin{tabular}{lcc}
\hline Değişken & $\bar{X}$ & SS \\
\hline Sır saklama & 20.96 & 6.64 \\
Idealleştirmeme & 14.10 & 2.71 \\
Bağımsızık & 10.93 & 2.19 \\
Bireyleşme & 13.52 & 2.88 \\
Duygusal Özerklik & 38.55 & 6.15 \\
Ahlaki Olgunluk & 282.05 & 21.07 \\
Sosyal Destek & 13.36 & 3.99 \\
Yalnızlık & 35.12 & 9.56 \\
Utangaçlık & 59.45 & 15.81 \\
\hline
\end{tabular}

Tablo 5'te görüldüğü üzere, katılımcıların sır saklama ölçeğinden aldıkları ortalama puan 20.96'tür. İdealleştirmeme alt ölçeğinden aldıkları ortalama puan 14.10, Bağımsızlık alt ölçeğinden aldıkları ortalama puan 10.93, Bireyleşme alt ölçeğinden aldıkları ortalama puan 13.52, Duygusal özerklik ölçeği toplam puan ortalaması 38.55, Ahlaki olgunluk ölçeğinden aldıkları ortalama puan 282.05 , Sosyal destek ölçeğinden aldıkları ortalama puan 13.36 , 
Yalnızlık ölçeğinden aldıkları ortalama puan 35.12 ve Utangaçlık ölçeğinden aldıkları ortalama puan ise 59,45 olarak bulunmuştur. Aşağıda, değişkenler arasındaki ilişkileri içeren korelasyon tablosu sunulmaktadır.

Tablo 6. Değişkenler Arasındaki Pearson Korelasyonları

\begin{tabular}{|c|c|c|c|c|c|c|c|c|}
\hline & $\begin{array}{l}\text { İdealleştir } \\
\text { meme }\end{array}$ & $\begin{array}{l}\text { Bağımsızl } \\
\text { ık }\end{array}$ & $\begin{array}{l}\text { Bireyleş } \\
\text { me }\end{array}$ & $\begin{array}{l}\text { Duygus } \\
\text { al } \\
\text { özerklik }\end{array}$ & $\begin{array}{l}\text { Ahlaki } \\
\text { olgunl } \\
\text { uk }\end{array}$ & $\begin{array}{l}\text { Sosyal } \\
\text { destek }\end{array}$ & $\begin{array}{l}\text { Yalnızlı } \\
\text { k }\end{array}$ & $\begin{array}{l}\text { Utangaçl } \\
\text { ık }\end{array}$ \\
\hline Sır Saklama & $-.17 *$ & $-.25 * *$ & $-.56 * *$ & $-.42 * *$ & $-.41 * *$ & $-.35 * *$ & $.56^{* *}$ & $.49 * *$ \\
\hline $\begin{array}{l}\text { İdealleştirme } \\
\text { me }\end{array}$ & 1.00 & $.51^{* *}$ & $.34 * *$ & $.78^{* *}$ & $.23 * *$ & $.51^{* *}$ & $-.23 * *$ & .044 \\
\hline Bağımsızlık & & 1.00 & $.48^{* *}$ & $.81 * *$ & $.48^{* *}$ & $.41^{* *}$ & $-.14 *$ & .04 \\
\hline Bireyleşme & & & 1.00 & $.79 * *$ & $.49 * *$ & $.54 * *$ & $-.41 * *$ & $-.28 * *$ \\
\hline $\begin{array}{l}\text { Duygusal } \\
\text { özerklik }\end{array}$ & & & & 1.00 & $.50 * *$ & $.62 * *$ & $-.34 * *$ & -.10 \\
\hline $\begin{array}{l}\text { Ahlaki } \\
\text { olgunluk }\end{array}$ & & & & & 1.00 & $.39 * *$ & $-.29 * *$ & $-.18 * *$ \\
\hline $\begin{array}{l}\text { Sosyal } \\
\text { destek }\end{array}$ & & & & & & 1.00 & $-.51^{* *}$ & $-.17 * *$ \\
\hline Yalnızlık & & & & & & & 1.00 & $.42 * *$ \\
\hline
\end{tabular}

${ }^{*} \mathrm{p}<.05 ;{ }^{* *} \mathrm{p}<.01$

Yordanan değişken ile yordayıcı değişkenler arasındaki ilişkiler çerçevesinde Tablo 6 incelendiğinde, sır saklama puanlarıyla idealleştirmeme, bağımsızlık ve bireyleşme alt ölçekleri, duygusal özerklik, ahlaki olgunluk ve sosyal destek puanları arasında negatif yönde manidar korelasyonlar elde edilmiştir. Sır saklama puanları ile yalnızlık ve utangaçlık puanları arasında pozitif yönde manidar korelasyonlar elde edilmiştir.

Yordanan değişkenle yordayıcı değişkenler arasındaki ilişkilere genel olarak bakıldığında sır saklama puanları ile bireyleşme, duygusal özerklik toplam puanları, ahlaki olgunluk, sosyal destek, yalnızlık ve utangaçlık puanları arasında orta düzeyde manidar ilişkiler olduğu görülmektedir. Korelasyon analiz sonuçları genel olarak değerlendirildiğinde orta ve düşük düzeyde manidar ilişkilerin elde edildiği gözlemlenmektedir.

\section{Regresyon analizi sonuçları:}

Araştırmanın bu bölümünde yordayıcı değişkenlerin (idealleştirmeme, bağımsızlık, bireyleşme, ahlaki olgunluk, sosyal destek, yalnızlık, utangaçlık) sır saklamayı yordama düzeylerini içeren aşamalı çoklu (stepwise) regresyon analizine ilişkin bulgu ve yorumlara yer verilmiştir. Ahlaki olgunluk, idealleştirmeme, bağımsızlık, bireyleşme, sosyal destek, yalnızlık ve utangaçıı değişkenlerinin, sır saklama değişkenini ne ölçüde yordadıklarını belirlemek amacıyla yapılan analizden elde edilen bulgular aşağıda verilmiştir. 
Tablo 7. Sır Saklama Puanlarının Yordanmasına ilişkin Aşamalı Çoklu Regresyon Analizi Sonuçları

\begin{tabular}{|c|c|c|c|c|c|c|c|}
\hline $\begin{array}{l}\text { Yordayıcı } \\
\text { Değişken }\end{array}$ & B & $R$ & $\mathrm{R}^{2}$ & $B$ & $B^{2}$ & $T$ & $p$ \\
\hline Sabit & 26.936 & & & & & 5.135 & .00 \\
\hline Bireyleşme & -.742 & $.557^{\mathrm{a}}$ & .310 & -.322 & .104 & -5.013 & .00 \\
\hline Yalnızlık & .227 & $.663^{b}$ & .440 & .326 & .106 & 5.396 & .00 \\
\hline Utangaçlık & .109 & $.705^{c}$ & .496 & .259 & .067 & 4.802 & .00 \\
\hline Ahlaki Olgunluk & -.040 & $.714^{\mathrm{d}}$ & .509 & -.127 & .016 & -2.185 & .030 \\
\hline Sosyal Destek & .165 & $.717^{\mathrm{e}}$ & .515 & .099 & .010 & 1.492 & .137 \\
\hline Bağımsızlık & -.157 & $.718^{f}$ & .516 & -.052 & .003 & -.810 & .419 \\
\hline İdealleştirmeme & .031 & $.718^{\mathrm{g}}$ & .516 & .013 & .000 & .212 & .832 \\
\hline$F: 33.065$ & & Sd:7;224 & & p:.000 & & & \\
\hline
\end{tabular}

Sır saklama $=26.936-.742$ Bireyleşme +.227 Yalnızlık +.109 Utangaçık -.040 Ahlaki olgunluk + .165 Sosyal Destek -.157 Bağımsızlık +.031 Idealleştirmeme

a Bireyleşme

${ }^{\mathrm{b}}$ Bireyleşme, Yalnızlık

'Bireyleşme, Yalnızlık, Utangaçlık

${ }^{\mathrm{d}}$ Bireyleşme, Yalnızlık, Utangaçlık, Ahlaki Olgunluk

e Bireyleşme, Yalnızlık, Utangaçlık, Ahlaki Olgunluk, Sosyal Destek

${ }^{f}$ Bireyleşme, Yalnızlık, Utangaçlık, Ahlaki Olgunluk, Sosyal Destek, Bağımsızlık

${ }^{g}$ Bireyleşme, Yalnızık, Utangaçlık, Ahlaki Olgunluk, Sosyal Destek, Bağımsızlık, İdealleştirmeme

Sır saklama değişkeninin yordanan değişken ve bireyleşme, yalnızlık, utangaçlık, ahlaki olgunluk, sosyal destek, bağımsızlık ve idealleştirmeme değişkenlerinin yordayıcı değişken olduğu regresyon modelinde, modelin istatistiksel olarak manidar olduğu bulunmuştur $\left.\left(F_{(7 ; 217)}\right)=33.065 ; \mathrm{p}<.01\right)$. Modelde yordayıcı değişkenler yordanan değişkendeki varyansın $\% 52$ 'sini açıklamaktadır. Tablo 7'de görüldüğü üzere, sır saklama değişkenine ilişkin varyansı en çok açıklayan değişken bireyleşme alt ölçeği puanlarıdır. Bunu sırasıyla yalnızlık, utangaçlık, ahlaki olgunluk, sosyal destek, bağımsızlık ve idealleştirmeme izlemektedir. Varyansa yaptıkları katkı açısından değişkenler değerlendirildiğinde bireyleşme ve yalnızlık ilk sırada yer almaktadırlar.

\section{SONUÇ, TARTIŞMA VE ÖNERILER}

Araştırmanın bu bölümünde araştırmanın amaçları çerçevesinde elde edilen bulgular tartışılmaktadır. Bu araştırma, duygusal özerklik (bireyleşme, bağımsızlık, idealleştirmeme), ahlaki olgunluk, yalnızlık, utangaçlık, sosyal destek ile sır saklama arasındaki ilişkiyi incelemek ve bu değişkenlerin sır saklamayı yordama düzeylerini incelemek amacıyla yapılmıştır.

$\mathrm{Bu}$ araştırmanın bulguları dikkate alındığında sır saklama düzeyinin cinsiyete göre farklılaşmadığı bulunmuştur. Araştırma kapsamında elde edilen bu bulgu ilgili alan yazını ile paralellik sergilemektedir. (Finkenauer ve diğ. 2002; Frinj ve diğ. 2005; Deniz, 2010). Alan yazınına bakıldığında kızlar ve erkekler arasında sır saklama açısından bir fark bulunmazken, kızların daha çok annelerine açıldıkları bulunmuştur (Youniss ve Smollar, 1985; Smetana, Metzger, Gettman, ve Campione-Barr, 2006 ). Ayrıca Noler ve Callan (1990) tarafindan yapılan bir araştırmada, ergen kızların daha çok annelerine açıldıkları, erkek ergenlerin ise anne babalarına eşit oranda açıldıkları tespit edilmiştir. bu araştırmadan elde edilen bulgular ışığında cinsiyetin sır saklamada belirleyici bir etken olmadığı değerlendirilmektedir. 
Araştırma kapsamında sır saklama düzeyinin sınıf düzeyine farklılaştığı ve on birinci sınıfta öğrenim görenlerin sır saklama düzeylerinin dokuzuncu sınıfta öğrenim gören bireylerin sır saklama puan ortalamalarından anlamlı düzeyde yüksek bulunmuştur. Elde edilen bu bulgu, sınıf düzeyi arttıkça sır saklamanın arttığına işaret ediyor olabilir.

Araştırma bulgularına göre, sır saklama düzeyinin bireylerin sahip olduğu kardeş sayısına göre farklılaşmadığı bulunmuştur. İlgili alan yazınına bakıldığında Deniz (2010) tarafından yapılan araştırmada tek kardeş ve üç kardeşe sahip ergenlere oranla beş ve üzeri sayıda kardeşe sahip olan ergenlerin sır saklama düzeylerinin daha yüksek olduğu bulunmuştur. Ancak bu araştırmada kardeş sayısının sır saklamada önemli bir değişken olmadığı sonucuna varılmıştır.

Bireylerin sır saklama düzeylerinin en uzun yaşanılan yerleşim birimine göre farklılaştığı ve bu farklılaşmanın en uzun süre köyde yaşayan bireylerin, şehirde uzun süre yaşayan bireylerin sır saklama düzeylerinden anlamlı bir şekilde farklılaştığı bulunmuştur. Deniz (2010) tarafından yapılmış olan araştırmada ilçede en uzun süre yaşayanların sır saklama puanlarının en uzun süre ilde oturanların sır saklama puanlarından daha yüksek olduğu bulunmuştur. Küçük yerleşim biriminde uzun süre yaşayan bireylerin toplumsal açıdan daha kolay kabul görmeleri ve reddedilmeyi engellemesi açısından bireyin istendik davranışlar sergilemesi dolayısıyla kendini gizlemesi eğiliminde olabileceği değerlendirilmektedir.

Bu araştırmanın korelasyon analiz sonuçlarına bakıldığında, sır saklama ile duygusal özerlik toplam puanı, duygusal özerlik alt ölçeklerinden idealleştirmeme, bağımsızlık ve bireyleşme arasında negatif bir ilişki bulunmuştur. Ayrıca sır saklama ile ahlaki olgunluk ve sosyal destek arasında negatif bir ilişki bulunmuştur. Öte yandan, sır saklama ile yalnızlık ve utangaçlık arasında pozitif bir ilişki bulunmuştur. Araştırmanın regresyon analiz sonuçları baz alındığında yordayıcı değişkenlerin sır saklama varyansının \%52'sini açıkladığı göze çarpmaktadır.

Sır saklama ile duygusal özerklik toplam puanı arasında negatif bir ilişki bulunmuştur. Bu bulgu sır saklamanın bireyin duygusal özerkliğini olumsuz etkilediği şeklinde yorumlanabilir. Sır saklama ile duygusal özerklik alt ölçeklerinden idealleştirmeme arasında negatif yönde bir ilişki bulunması ulaşılabilen alan yazını ile paralellik göstermektedir (Deniz, 2010). Ayrıca bireyin ebeveynlerini idealleştirmemesi yoluyla kendi kimliklerini oluşturmalarına katkı sağlayacağı şeklinde değerlendirilmektedir (Frank, Pirsche ve Wringht. 1990). Sır saklama ile bireyleşme arasında negatif yönde bir ilişki bulunması ulaşılabilen alan yazını ile paralellik gösteren çalışmanın olduğu yönündedir (Deniz,2010). Elde edilen bulgu neticesinde sır saklamanın bireyleşmeyi olumsuz etkilediği şeklindedir. Öte yandan sır saklamanın bireyleşmeyi kolaylaştırdığı sonucunun elde edildiği çalışmalar da mevcuttur (Finkeanuer ve diğ., 2002; Frinj ve diğ., 2005). Türkiye'deki toplulukçu kültürel yapının bir parçası olarak bireyin üyesi olduğu topluluğun yaşam biçimine ayak uydurmasının bir sonucu olarak değerlendirilmektedir. Sır saklama ile bağımsızlık alt ölçeği arasında negatif bir ilişki bulunmuştur. Ulaşılabilen alan yazınında benzer bulgulara ulaşılamamıştır. Bu bulgu değerlendirildiğinde, sır saklama bireyin bağımsızlığını olumsuz etkilediği şeklinde yorumlanabilir.

Bu araştırmada sır saklama ile ahlaki olgunluk arasında negatif yönde bir bulgu elde edilmiştir. Ulaşılabilen alan yazınında ahlaki alan ile ilgili olan konularda ergenlerin sır saklama eğiliminde oldukları değerlendirilmektedir (Smetana, 2006). Bu araştırmada da ahlaki olgunluk ile sır saklama arasında negatif yönde bir ilişki bulunmuştur. Araştırma bulguları değerlendirildiğinde, ahlaki olgunluk düzeyi yükseldikçe sır saklama düştüğü şeklinde yorumlanabilir. 
Sır saklama ile algılanan sosyal destek arasında negatif yönde bir ilişki bulunmuştur. Ulaşılabilen alan yazınında anababa ile güçlü ilişkinin bireyin düşük sır saklamasını sağladığı yönündedir (Bumpus ve Hill, 2003). Sır saklama ile ilgili yapılmış olan araştırmalarda ergenlerin sırlarını daha çok annelerine açma eğiliminde oldukları bulunmuştur (Smetana ve diğ., 2006). $\mathrm{Bu}$ araştırmada elde edilen bulgu değerlendirildiğinde, ailesinden destek gören bireylerin sır saklama eğiliminde olmadığı şeklinde yorumlanabilir.

Sır saklama ile yalnızlık arasında pozitif yönde bir bulgu elde edilmiş olup, ulaşılabilen alan yazınıyla benzerlik göstermektedir (Frinj ve Finkenauer, 2008). Bu bulgu doğrultusunda sır saklayanların daha yalnız olduğu söylenebilir. Sır saklama ile utangaçlık arasında pozitif yönde bir bulgu elde edilmiştir. Ulaşılabilen alan yazınında sır saklayan bireylerin utangaç olduklarına yönelik bulgular elde edilmiştir (Kelly, 1999). Bu araştırma kapsamında elde edilen bulguda sır saklanın bireyin utangaçığı ile ilişkili bulunmuştur. Yani utangaç olan bireylerin daha çok sır saklama eğilimde oldukları şeklinde yorumlanabilir.

Araştırmadan elde edilen bulgular katılımcıların ölçme araçlarına verdikleri yanıtlara dayanmaktadır. Özellikle, sır saklama ve duygusal özerklik gibi değişkenlerin kültüre dayalı bir biçimde farklılaştığı yapılan araştırmalarla ortaya konduğundan, bundan sonra yapılacak çalışmaların bu yapıların kültüre özgü boyutunu belirlemesi açısından karma araştırma yönteminin kullanılmasının yararlı olacağı düşünülmektedir. Ergenlerde sır saklama ile ilgili yapılacak araştırmalarda, anababaların gözlemlerine de yer verilmesi önemli görülmektedir. Ayrıca, sır saklamanın anababa tutumları ile ilişkisine bakılabilir. Ergenlerde sır saklama ile ilgili bundan sonra yapılacak çalışmalar farklı çalışma grupları üzerinde gerçekleştirilerek sonuçlar karşılaştırılabilir.

\section{KAYNAKLAR}

Aadlansvik, R. (1997). Secrecy and the development of personal identity- A challenge for parents and the theachers in our time. Teaching \& Teacher Education, 13 (3), 363-368.

Bandura, A. (2001). Social Cognitive Theory: An Agentic Perspective. Annual Review of Psychology. Vol.:52. pp.1-26.

Bok, S. (1989). Secrects: On the ethics of concealment and revelation. New York: Vintage books.

Bumpus, M. F. and Hill, L. G. (2008). Secrecy and parent-child communication during middle childhood: Associations with parental knowledge and child adjustment. Parenting: Science and Practice. 8, 93-116.

Cheek, J. M., and Briggs, S.R. (1990). Shyness and personality trait, shyness and Embarrasment: Perspectives from social psycholog. Cambridge: Cambridge University Press.

Çileli, M. (1981). 14-18 yaşları arasındaki öğrencilerde ahlaki yargının zihinsel gelişim psikolojisi yaklaşımı ile değerlendirilmesi. (Yayımlanmamış Doktora Tezi). Ankara Üniversitesi. Ankara.

Demir, A. (1989). "UCLA yalnızlık ölçeğinin geçerlik ve güvenirlik çalışması". Türk Psikoloji Dergisi, 7,23, 14-18.

Deniz, M. (2010). Ergenlerde sır saklamanın duygusal ve gelişimsel değişkenler açısından incelenmesi. (Yayımlanmamış Doktora Tezi). Ankara Üniversitesi. Ankara. 
Deniz, M. ve Çok, F. (2010). Kendini gizleme ölçeğinin ergenler için uyarlanması ve psikometrik nitelikleri. Ilköğretim Online, 9 (1), 424-432.

Deniz, M., Çok, F., ve Duyan, V. (2013). Duygusal özerklik ölçeği'nin ergenler için uyarlanması ve psikometrik özellikleri. Eğitim ve Bilim, 38(167).

Enç, M. (1980). Ruh bilim terimleri sözlüğüü. Ankara: Türk Dil Kurumu Yayınları.

Eskin, M. (1993). Reliability of the Turkish version of perceived social support from friends and family scales, scale for interpersonal behavior and suicide probability scale. Journal of Clinical Psychology. 49(4): 515-523.

Finkenauer, C., Engels, R. C. M. E. and Meeus, W. (2002). Keeping secrects from parents: Advantages and disadvantages of secrecy in adolescence. Journal of Youth and Adolescence. 2, 123-136.

Frank, S.J., Pirsch, L.A., and Wright, V.C. (1990). Late adolescents perception of their relationships with their parents: Relationships among deidealization autonomy, relatedness and insecurity and implications for adolescent adjustment and ego identity status. Journal of Youth and Adolescence. 19, 6, 571-588.

Freud, S. (1997). Psikanaliz Üzerine. (Çev.: A. Avni Öneş). İstanbul: Say Yayınları.

Frinj, T., Finkenauer, C., Vermulst, A. A. and Engels, R. C. M. E. (2005). Keeping secrects from parents: Longitudinal associations of secrecy in adolescence. Jounal of Youth and Adolescence, 34 (2), 137-148.

Frinj, T. and Finkenauer, C. (2008). Longitudinal associations between keeping a secret and psychosocial adjustment in adolescence. International Journal of Behavioral Development. 33 (2), 145-154.

Gün, F. (2006). Kent kültüründe yalnızlık duygusu. (Yayımlanmamış yüksek lisans tezi). Ankara Üniversitesi. Ankara.

Güngör, A. (2001), Utangaçlık ölçeğinin geliştirilmesi, geçerlik ve güvenirlik çalışması, Türk Psikolojik Danışmanlık ve Rehberlik Dergisi, c.2, ss. 17-22.

Hamarta, E., \& Demirbaş, E. (2009). Lise öğrencilerinin utangaçlık ve benlik saygılarının fonksiyonel olmayan tutumlar açısından incelenmesi. Selçuk Üniversitesi Sosyal Bilimler Enstitüsü Dergisi, (21), 239-247.

Karasar, N. (2004). Bilimsel araştırma yöntemi. Ankara: Nobel Yanın Dağıtım.

Kelly, A. E. and Mckillop, K. J. (1996). Consequences of revealing personal secrets. Psychological Bulletin. 20, (3), 450-465.

Kelly, A. E. (1999). Revealing personal secrects. Current Directions in Psychological Science. 8, 105-109.

Kelly, A. E. (2002). The psychology of secrets. New York: Plenum publishers.

Kohlberg, L. (1980). Kohlberg on Moral Development and Moral Education: B. Munsey (Ed.), Moral Development, Moral Education and Kohlberg: Basic İssues in Philosophy, Psychology, Religion, and Education, ss. 15-100, Alabama, Religious Education Press. 
Larson, D. G. and Chastain, R. L. (1990). Self-concealment: Conceptualization, measurement and health implications. Journal of Social and Clinical Psychology. 69, 237-253.

Lickona, Thomas E. (1991). Educating for Character: How Our Schools can Teach Respect and Responsibility. New York: Bantam Books.

Noller, P. and Callan, V. J. (1990). Adolescents' perceptions of the nature of their communication with parents. Journal of Youth and Adolescence. 19, 349-362.

Noom, M., Dekovic, M., and Meeus, W. (2001). Conceptual analysis and measurement of adolescent autonomy. Journal of Youth and Adolescence, 30(5), 577-595.

Nucci, L. P. (1981). The development of personal concepts: A domain distinct from moral or societal concepts. Child Development. 52, 114-121.

Özkürkçügil A. Ç. (1998). Cezaevinde yalnızlık ve yalnızlığın depresyonla ilişkisi. Kriz Dergisi. 6:21-32.

Piaget, J. (2004). Çocukta Zihinsel Gelişim. (Çev.: Hüseyin Portakal). İstanbul: Cem Yayıncılık.

Russell, D , Peplau, L. A.. and Ferguson, M. L. (1978). Developing a measure of loneliness. Journal of Personality Assessment. 42, 290-294.

Smetana, J.G. (2006). Social-cognitive domain theory: Consistencies and variations in children's moral and social judgments. In: M.E. Killen and J. Smetana, Editors, Handbook of Moral Development, Erlbaum, Mahwah, NJ pp. 119-153.

Smetana, J. G., Metzger, A., Gettman, D. C. and Campione-Barr, N. (2006). Disclosure and secrecy in adolescent-parent relationships. Child Development. 77 (1), 201-207.

Smetana, J. G., Villalobos, M., Tasopoulos-Chan, M., Gettman, D. C., and Campione-Barr, N. (2009). Early and middle adolescents' disclosure to parents about their activities in different domains. Journal of Adolescence. 32, 693-713.

Steinberg, L. and Silverberg, S. B. (1986). The vicissitudes of autonomy in early adolescence. Child Development, 57, 841- 851.

Steinberg, L. (2007). Ergenlik. (Çev. Editörü: Çok, F.) Ankara: İmge Kitabevi.

Steptoe A, Owen N, Kunz-Ebrecht S, and Brydon L.(2004). Loneliness and neuroendocrine, cardiovascular, and inflammatory stres responses in middle-aged men and women. Psychoneuroendocrino. 29: 593-611.

Şengün, M. and Kaya, M. (2007).Ahlaki Olgunluk Ölçeği: Geçerlik ve Güvenirlik Çalışması. Ondokuz Mayıs Üniversitesi Ilahiyat Fakültesi Dergisi. Sayı: 24-25,ss.51-64.

Turiel, E. (1983). The development of social knowledge: Morality and Convention. Cambridge: Cambridge University Press.

Youniss, J. and Smollar, J. (1985). Adolescents' relations with mothers, fathers, and friends. Chicago: Chicago University Press. 


\section{SUMMARY}

With the transition to adolescence, adolescents communication and interaction style with their family and peers begin to change. The people may tend to keep secrets from others for various reasons or can share things can be regarded as secrets with a limited number of people. Secrets that are hiden by the people is seen as generally differ from privacy. The information within this particular area, in accordance with the request of people may not be shared even with the others who are closest to him/her. In this respect privacy and secrets are considered as different from each other. However, secrecy is seen as a risky period for adolescence especially in some cultural structures. Secrecy is that keeping any information actively and consciously from (at least) one other person. There are many theoretical explanations of secrecy. According to the Inhibition theory secrecy requires active supression or inhibition of feelings that cause some harmful effect such as physical and psychological complaint. The individual develops a number of judgments in the context of moral development, in order to open secrets about himself or others to others. When considered in this context, it can be considered that there is a close relationship between mysterious retention and moral maturity. Although adolescent mysticism has been shown to contribute to its individualization, it has been determined that mental retardation causes a number of physical complaints and psychosocial problems that can be generally considered as negative.

This study is based on general scanning model. This model aims to describe a past or present case in its original form. In this study, secrecy is dependent variable whereas moral maturity, emotional autonomy, loneliness, shyness and social support are independent variables. The sample of this study consists of totally 225 students (160 female and 65 male), attending 9, 10, 11 grades at high schools in the period of 2013-2014 academic year. The age of the participants ranged from 15- 19 years with a mean of 16.2 years. Also, $15.6 \%(n=35)$ of the participants are 9 grade, $53.3 \%(n=120)$ of the participants are 10 grade and $31.1 \%(n=70)$ of the participants are 11 grade. The "Self Concealment Scale ", " Emotional Autonomy Scale ", " Moral Maturity Scale ", " UCLA Loneliness Scale ", " Shyness Scale " and "Social Support Scale " were used in this study.

This study was conducted to investigate the relationship between secrecy, emotional autonomy (individuation, independence, idealization), moral maturity, loneliness, shyness, social support. This study also examined the differences in the level of secrecy of adolescents according to gender, number of siblings, grade level and the place of residence where they live the longest. As a result of this study, it was found that the level of secrecy of adolescents participating in the study did not differ according to the sex and the number of siblings. On the other hand, the level of secrecy was found to differ according to the grade level of the adolescents and the longest place of residence. When we look at the relations between predicted and predictive variables, there is positive correlations between secrecy and lonelines and shyness. Also, negative correlation was found between secrecy, moral maturity, emotional autonomy (idealization, individuation, independence) and social support. In addition, it was evaluated that the regression model was statistically significant.

Findings obtained from the study are based on the participants' questionnaire forms. Especially variables such as secrecy and emotional autonomy are revealed through researches that are differentiated in a culture-based manner, it is thought that it is useful to use the mixed research method in order to determine the cultural specific dimension of these structures. It is important to include the observations of parents in the researches to be carried out regarding the secrecy of adolescents. In addition, the relationship between secrecy and parental attitudes can be investigated. For further studies on secrecy in adolescents can be carried out on different working groups and the results can be compared. 